
\title{
CS Research Square \\ The non-traditional and familial risk factors for preeclampsia in the FINNPEC cohort
}

\section{Noora Sofia Jaatinen ( $\nabla$ nskive@utu.fi )}

Turku University Central Hospital and University of Turku, Turku, Finland https://orcid.org/0000-00028484-0976

\section{Tiina Jääskeläinen}

University of Helsinki and Helsinki University Hospital

\section{Hannele Laivuori}

Tampere University hospital and University of Tampere

\section{Eeva Ekholm}

Turku University Central Hospital and University of Turku

\section{Research article}

Keywords: preeclampsia, pregnancy, pregnancy complication, reproduction, risk factor

Posted Date: October 30th, 2019

DOI: https://doi.org/10.21203/rs.2.16612/v1

License: (c) (1) This work is licensed under a Creative Commons Attribution 4.0 International License. Read Full License

Version of Record: A version of this preprint was published at Pregnancy Hypertension on March 1st, 2021. See the published version at https://doi.org/10.1016/j.preghy.2020.11.001. 


\section{Abstract}

Background Considering the burden of preeclampsia (PE), it is important to understand better the underlying risk factors involved in its etiology. In this nationwide study, we studied the association of background factors with PE with an emphasis on socioeconomic factors, reproductive factors and health history enclosing the parents of pregnant women.

Methods In the Finnish Genetics of Pre-eclampsia Consortium (FINNPEC) cohort participants filled in a questionnaire on background information including data on socioeconomic factors, health history and reproductive factors. The questionnaire data was available from 708 women with PE and 724 control women. Two different control groups, healthy controls with uncomplicated pregnancies $(n=498)$ and all controls ( $n=724$, including controls with uncomplicated pregnancies and pregnancy complications other than $\mathrm{PE})$, were established. Background information among PE women and the two different control groups were compared.

Results PE women had similar socioeconomic status and more often non-communicable diseases including type I diabetes, chronic hypertension and hyperlipidemia than the two control groups ( $p<0.05$ for all). Depression was more common among PE women $(11.4 \%)$ than among all controls $(7.6 \%)(p=0.019)$. Subfertility (estimated by time to pregnancy) was more common among PE women ( $p=0.013$ for healthy controls, $p=0.019$ for all controls). PE women had earlier menarche $(p=0.001$ for healthy controls, $p=0.022$ for all controls). Hypertension was more common in both parents of PE women ( $p<0.001)$, stroke in fathers (PE women $6.2 \%$, healthy controls $3.2 \%(p=0.020)$ and all controls $3.5 \%(p=0.022))$ and diabetes in mothers (PE women $7.5 \%$, healthy controls $3.1 \%(p=0.001)$ and all controls $4.3 \%(p=0.012))$. Mental disorders including depression were more common in mothers of PE women compared to controls (PE women $7.2 \%$, healthy controls $3.7 \%(p=0.013)$ and all controls $3.9 \%(p=0.007))$.

Conclusions In this Finnish nationwide FINNPEC cohort, PE women had similar socioeconomic status, more non-communicable diseases and depression, earlier menarche, more subfertility and more parental noncommunicable diseases compared to controls. As a novel finding we found more mental disorders including depression in mothers of PE women.

\section{Background}

Preeclampsia (PE) is a pregnancy complication characterized by coexistence of hypertension and one or more of the following new-onset conditions: proteinuria, other maternal organ dysfunction or uteroplacental dysfunction (1). It affects 3-5\% of pregnancies and is a major cause of maternal, fetal and neonatal mortality and morbidity (2). The etiology of PE remains unclear but reduced placental perfusion and inflammation associating with oxidative stress and endothelial dysfunction are considered as central features in its pathogenesis. Maternal genetic, behavioral and metabolic factors are thought to contribute to the PE phenotype (3). Several maternal risk factors for $P E$ have been identified such as previous $P E$, chronic hypertension, pregestational diabetes, body mass index $(\mathrm{BMI})>30 \mathrm{~kg} / \mathrm{m}^{2}$, use of assisted reproductive technology (ART), chronic kidney disease, antiphospholipid syndrome and other autoimmune disorders $(2,4)$. However, known clinical risk factors are predictive only in $30 \%$ of PE women (2). 
The information on other characteristics or exposures as risk factors for PE is inconsistent and/or modest. Low socioeconomic status is associated with PE in most (5-8) but not all studies $(9,10)$. Previously only few studies have assessed the association with childhood socioeconomic status and PE $(10,11)$. An increasing amount of studies have investigated the association between PE and use of medication. In a systematic review antidepressant use during the second trimester was associated with an increased risk of PE (12). Whether antidepressants or underlying depression affect the risk of PE independently remains uncertain, because depression itself is related to $\mathrm{PE}(13,14)$. Family history of hypertension and cardiovascular disease (CVD) have been shown to increase risk for PE (15) but to our knowledge, family history of depression has not been studied. Few studies have addressed the association of age at menarche with the risk of PE and the results have been conflicting. Early age at menarche has been associated with PE in a few $(16,17)$ but not all studies (18).

Identifying women at risk for PE is important in early pregnancy because strategies to prevent PE are available. Aspirin initiated at $\leq 14$ weeks of gestation reduces the risk of preterm PE in women with high risk for PE (19). Since traditional risk factors predict only $30 \%$ of women who develop PE later in pregnancy, we focused on less explored risk factors: socioeconomic factors, health history including the parents of the study participants and reproductive factors. (2).

\section{Methods}

\section{Study design}

Data was derived from the prospective arm of the Finnish Genetics of Pre-eclampsia Consortium (FINNPEC) cohort. FINNPEC, a cross-sectional case-control multicentre study, was established to set up a nationwide clinical and DNA database on women with and without PE including their partners and infants in order to identify genetic risk factors for PE. Details of the study design, methods and procedures have been described in the FINNPEC cohort profile (20).

\section{Study subjects}

In the current study, we included 923 women with PE and 1009 controls recruited during 2008-2011. The inclusion criteria were age above 18 years, a singleton pregnancy and ability to provide an informed consent based on information in Finnish or Swedish. Using the American College of Obstetricians and Gynecologists (ACOG) 2002 criteria, PE was defined as hypertension and proteinuria (21). Hypertension was defined as systolic blood pressure $\geq 140 \mathrm{mmHg}$ and/or diastolic blood pressure $\geq 90 \mathrm{mmHg}$ after 20 weeks of gestation. Proteinuria was defined as the urinary excretion of $\geq 0.3 \mathrm{~g}$ protein in a 24 -hour specimen, or $0.3 \mathrm{~g} / \mathrm{l}$, or two $\geq 1+$ readings on dipstick in a random urine sample with no evidence of a urinary tract infection. Each diagnosis was confirmed independently from medical records by a research nurse and a research physician. The FINNPEC study protocol was approved by the coordinating Ethics Committee of the Hospital District of Helsinki and Uusimaa. 
The participants were asked to fill a detailed questionnaire on background information including data on socioeconomic factors, health history and reproductive factors. Information on pre-pregnancy weight and height, obstetric history, pregnancy outcome, delivery and newborn was obtained from the hospital records and maternity cards. Data on smoking were collected from the maternity cards and complemented from the background information questionnaires. The participants filled in the questionnaire during pregnancy, or shortly after delivery.

A detailed questionnaire on background information was available from 708 women with PE $(76.7 \%)$ and 724 control women $(71.8 \%)$. Two different control groups were established for the current study. A subgroup of healthy controls consisted of 498 healthy women with uncomplicated pregnancies. All controls $(\mathrm{n}=724)$ included also women with other pregnancy complications than PE.

\section{Statistical analysis}

Statistical analyses were performed using SPSS Statistics 23.0 (IBM Corp., Armonk, NY, USA). Background information among PE women and the two different control groups were compared separately (PE vs. healthy controls and PE vs. all controls). The normality of distributions was verified graphically and with the Kolmogorov-Smirnov-test. Statistical analyses of continuous variables were performed using the two-sample t-test for normal and Mann-Whitney U-test for skewed distributions. For categorical variables comparisons between the groups were performed with the Chi-square test. $P$ value of $<0.05$ was considered as statistically significant.

\section{Results}

\section{Basic characteristics of the study population}

Basic characteristics of the study participants are presented in Table 1. Women with PE were more often nulliparous and had a higher BMI than women in the two control groups. They delivered earlier and more often with a caesarean section. PE women who did not respond to the questionnaire were more often multiparous, had a higher $\mathrm{BMI}$ and delivered earlier and more often with a caesarean section compared to responding PE women. There were no differences in the background factors between the respondents and non-respondents in the control groups (data not shown).

\section{Socioeconomic factors}

Socioeconomic factors of the study participants are presented in Table 2. Women with PE were more often employed and they worked more hours/week than women in the two control groups. However, when the women without employment (including housewives, students and unemployed) were excluded, there was no difference in the weekly working hours between the groups. PE women reported more unemployment during the 12 months preceding delivery. Women in the control groups were more often housewives and married. 
There were no differences in education level, income and area of residence between the PE women and controls.

\section{Health history}

Information on the participants' health and pregnancies is shown in Table 3. The subjective health of the women suffering from PE was poorer. PE women had more often pre-existing medical conditions (Table 4) including type I diabetes, chronic hypertension, hyperlipidemia and depression. The use of any regular or seasonal medication did not differ between women with PE and all controls (Table 5). When compared to healthy controls, women with PE used more often selective serotonin reuptake inhibitors (SSRIs) and metformin. Women with PE were more often on insulin and antihypertensive medication, including medications used before pregnancy, than women in the two control groups. Reported oral health was found similar between women with PE and all controls. However, women with PE were more often treated for tooth decay than the healthy controls (data not shown).

\section{Reproductive factors}

Menarche occurred earlier in the women with PE compared to the control groups (Table 3). It took more time to conceive for women with PE, more than twelve months for $16.7 \%$ of women with PE, for $12.4 \%$ of healthy controls and for $12.8 \%$ of all controls. The use of ART did not differ between the groups.

\section{Study participants' parents}

Education and medical history of the index patient's family is presented in Table 6. The fathers of the women in the control groups had higher education than those of the women with PE, whereas there were no differences regarding the education of the participants' mothers. Both parents of PE women suffered more often from hypertension than the parents of the women in the two control groups. Also stroke was more prevalent in the fathers of the women with PE. Diabetes and mental disorders, including depression, were more common in mothers of PE women. Furthermore, PE women were more often born from a pregnancy complicated by PE than the women in the control groups.

\section{Discussion}

In this Finnish nationwide FINNPEC cohort, women with PE had similar socioeconomic status, more noncommunicable diseases and depression, earlier menarche and more subfertility compared to controls. Hypertension was more common in both parents, stroke in fathers and diabetes and mental disorders including depression in mothers of PE women compared to controls.

The socioeconomic status of the study groups was similar estimated both by education and income which is in line with some previous studies $(9,10)$. In contrast, several previous studies have reported an association between low socioeconomic status and PE $(5-8)$ when maternal education $(5,6)$ or income $(7,8)$ have been 
used as indicators of socioeconomic status. It remains unclear whether the association between PE and low socioeconomic status found in some studies is attributed to inadequate prenatal care or to low socioeconomic status itself. Inadequate prenatal care is associated with $\mathrm{PE}$, and women with low socioeconomic status are less likely to receive adequate prenatal care (7). In Finland services of the maternity clinics are free of charge and of high-quality and used by more than $90 \%$ of pregnant women. Thus, inadequate prenatal care is not likely to be an intermediating factor in our population. Furthermore, in Finland there are fairly small differences between social classes and education is costless also at university level.

Only few studies have explored the association between socioeconomic status in childhood and adulthood and hypertensive pregnancy disorders. Studies carried out in Sweden and in the UK found that neither childhood nor adulthood socioeconomic status were related to PE $(10,11)$. In our study there was no difference in the socioeconomic status regarding mothers of the study participants, but the fathers of the women in the control groups had a higher education level. The results are not completely comparable with previous studies which used both education, family social class (11) and childhood social class based on occupation of study participants' fathers (10) as indicators of socioeconomic status.

We found that women with PE were more often employed than the women in the control groups. Yet there was more unemployment among PE women during the last 12 months. This is probably due to the fact that women in the control groups were more often multiparous and housewives. Among employed women, the weekly working hours did not differ between the groups, in line with previous studies $(22,23)$. A Dutch cohort study found no difference in the risk of PE between employed and unemployed women. They also compared the risk of PE among women experiencing different types of unemployment and reported that housewives and job-seeking women had a similar risk of PE as employed women. However, when compared to housewives, job-seeking women had a higher risk for PE. (23) The discrepancy with our results may be partly due to a smaller number of PE women in the Dutch cohort. In addition, the population of the Dutch study was somewhat different concerning employment. The percentage of all employed women was $72 \%$ in the Dutch study compared to $66.8 \%$ for PE women, $54.3 \%$ for healthy controls and $56.3 \%$ for all controls in the present study.

Our data suggest that the overall health was worse in the women developing PE compared to the control women. The known clinical risk factors for PE such as pregestational diabetes, chronic hypertension and hyperlipidemia were more prevalent also in this study population $(2,4,24)$.

Our finding on increased incidence of depression among women with PE is in line with the results of two meta-analyses $(13,14)$ which showed that both a history of depression and depressive symptoms during pregnancy are associated with an increased risk of PE. Depression and PE may share common pathophysiologic pathways since inflammation and oxidative stress are associated both with depression and PE $(3,25)$. The use of SSRIs was higher among women with PE than controls with uncomplicated pregnancy, but there were no differences when the women with PE were compared to all controls. A systematic review of seven studies showed that the use of antidepressants during the second trimester of pregnancy was associated with a modestly increased risk of PE or gestational hypertension (12). The risk of PE appeared to be low in patients using SSRIs or serotonin-norepinephrine reuptake inhibitors and remains 
inconclusive in patients using tricyclic antidepressants. The data on the association of antidepressive medication and PE are inconsistent (12). Recently, Lupattelli et al. reported that SSRI use in early and midpregnancy did not increase the risk of late-onset PE (26). De Oecampo et al. showed that women who continued to use antidepressants of two or more classes during the second half of pregnancy had increased risk for $P E$, whereas the use of any single antidepressant was not connected to increased risk for PE (27). It remains unclear whether depression itself or the antidepressive medication independently relate to PE. Further research is needed to indicate whether there is an association between antidepressant use during pregnancy and the development of PE.

The parents of PE patients had more morbidity compared to those of the controls' including hypertension which is in line with some previous studies $(15,28,29)$. Family history of CVDs including stroke $(15,29)$ and type II diabetes (30) have been shown to increase risk of PE. Our findings on fathers of the PE women suffering from stroke and mothers with diabetes are in accordance with previous data. We also found an increased incidence of mental disorders including depression among PE womens' mothers. To our knowledge there is no previous published research on this topic.

Earlier menarche in women with PE compared to the women in control groups is in line with some previous studies $(16,17)$. Higher BMI may partly mediate this association (17). Early age at menarche has been associated to gestational diabetes (31) and CVD (32). Gestational diabetes (33) and future cardiovascular morbidity (34) have been shown to be associated with PE as well. In our study women with PE had more often risk factors for metabolic syndrome, like higher BMI, which also associates with earlier menarche. This may partly explain our finding on earlier menarche with PE women. In a recent study Petry et al. found a negative association between age at menarche and subsequent blood pressure in pregnancy, but not independently with the risk of PE (35). Their results were attenuated byincreased BMI and insulin resistance. The researchers suggested that the associations between blood pressure and age at menarche are mediated by obesity and/or insulin resistance. Alternatively, there may be a common pathophysiological mechanism like systemic inflammation that links age at menarche to each of these metabolic risk factors (35). Indeed, a negative correlation between age at menarche and circulating C-reactive protein concentrations has been reported suggesting a link between early age at menarche and inflammation (36). Insulin resistance and increased blood pressure may result from low grade systemic inflammation occurring as a result of increased macrophage infiltration of adipose tissue (35). CVD is also associated with systemic inflammation with adipose tissue being a significant contributor to the inflammatory state (37). The associations between $\mathrm{PE}$, early age at menarche, insulin resistance and CVD may be explained by obesity or systemic inflammation or both. Future studies are needed to better understand these associations.

Although infertility treatments were as frequent in all groups, conceiving took more time for women with PE. In line with our findings, previous studies have shown that subfertile women are at increased risk for PE (3842). It is well recognised that pregnancies following ART are at higher risk for PE when compared with those after natural conception (43-45). Similar underlying causes may be behind PE and infertility. Hayashi et al. found that adverse obstetric outcomes in singleton pregnancies after ART may be related to maternal factors associated with infertility rather than the type of ART used (46). Inflammation and/or obesity have been 
suggested as possible mechanisms linking subfertility with PE (47). These conditions may also associate PE with early age at menarche, CVD and insulin resistance.

\section{Strengths and limitations}

The main strength of this study is a nationwide and population based cohort with detailed information from medical records. Further, background information was collected on a wide basis comprising health, lifestyle and health history of the parents of the pregnant women. The response rates to the study's questionnaires were good (PE women $76.7 \%$ and control women $71.8 \%$ ) considering that a response rate of $60 \%$ has face validity as a measure of survey quality (48). On the other hand PE nonrespondents differed somewhat from $P E$ respondents and this may have biased some results of the study.Information gained through questionnaires is subjective, which can be considered a limitation of this study. The completeness and accuracy of information varies from case to case.

\section{Conclusions}

In this Finnish nationwide FINNPEC cohort, PE women had similar socioeconomic status, more noncommunicable diseases and depression, earlier menarche, more subfertility and more parental noncommunicable diseases compared to controls. As a novel finding we found more mental disorders including depression in mothers of PE women. More attention should be paid to depression/depressive symptoms and family health history of depression in addition to somatic diseases in antenatal care.

\section{Abbreviations}

PE: Preeclampsia

FINNPEC: The Finnish Genetics of Pre-eclampsia Consortium

BMI: Body mass index

ART: Assisted reproductive technology

CVD: Cardiovascular disease

ACOG: The American College of Obstetricians and Gynecologists

SSRI: Selective serotonin reuptake inhibitor

\section{References}

1. Tranquilli AL, Dekker G, Magee L, Roberts J, Sibai BM, Steyn W, et al. The classification, diagnosis and management of the hypertensive disorders of pregnancy: A revised statement from the ISSHP. Pregnancy Hypertens. 2014;4(2):97-104. 
2. Mol BWJ, Roberts CT, Thangaratinam S, Magee LA, De Groot CJM, Hofmeyr GJ. Pre-eclampsia. Lancet. 2016;387(10022):999-1011.

3. Roberts JM, Bell MJ. If we know so much about preeclampsia, why haven't we cured the disease? J Reprod Immunol. 2013 Sep; 99(1-2): 1-9.

4. Bartsch E, Medcalf KE, Park AL, Ray JG, Al-Rubaie ZTA, Askie LM, et al. Clinical risk factors for preeclampsia determined in early pregnancy: Systematic review and meta-analysis of large cohort studies. BMJ. 2016;353: i753. doi: 10.1136/bmj.i1753.

5. Silva LM, Coolman M, Steegers EAP, Jaddoe VW, Moll HA, Hofman A, et al. Low socioeconomic status is a risk factor for preeclampsia : the Generation R Study. J Hypertens. 2008;26(6):1200-1208.

6. Bilano VL, Ota E, Ganchimeg T, Mori R, Souza JP. Risk factors of pre-eclampsia/eclampsia and its adverse outcomes in low- and middle-income countries: a WHO secondary analysis. PLoS ONE. 2014; 9(3): e91198. doi:10.1371/journal.pone.0091198

7. Kim MK, Lee SM, Bae S-H, Kim HJ, Lim NG, Yoon S-J, et al. Socioeconomic status can affect pregnancy outcomes and complications, even with a universal healthcare system. Int J Equity Health. 2018;17(1):2.

8. Choe S-A, Min H-S, Cho S-I. The income-based disparities in preeclampsia and postpartum hemorrhage: a study of the Korean National Health Insurance cohort data from 2002 to 2013. Springerplus. 2016;5(1):895.

9. Sibai BM, Gordon T, Thom E, Caritis SN, Klebanoff M, McNellis D, et al. Risk factors for preeclampsia in healthy nulliparous women: A prospective multicenter study. Am J Obstet Gynecol. 1995;172:642-8.

10. Lawlor DA, Morton SMB, Nitsch D, Leon DA. Association between childhood and adulthood socioeconomic position and pregnancy induced hypertension: Results from the Aberdeen children of the 1950s cohort study. J Epidemiol Community Health. 2005;59(1):49-55.

11. Heshmati A, Mishra G, Koupil I. Childhood and adulthood socio-economic position and hypertensive disorders in pregnancy: The uppsala birth cohort multigenerational study. $\mathrm{J}$ Epidemiol Community Health. 2013;67(11):939-46.

12. Uguz F. Is There Any Association between Use of Antidepressants and Preeclampsia or Gestational Hypertension: A Systematic Review of Current Studies. J Clin Psychopharmacol. 2017;37(1):72-77.

13. Hu R, Li Y, Zhang Z, Yan W. Antenatal depressive symptoms and the risk of preeclampsia or operative deliveries: A meta-analysis. PLoS ONE 10(3): e0119018. doi:10.1371/ journal.pone.0119018

14. Zhang S, Ding Z, Liu H, Chen Z, Wu J, Zhang Y, et al. Association between mental stress and gestational hypertension/ preeclampsia: A meta-analysis. Obstet Gynecol Surv. 2013;68(12):825-34.

15. Ness RB, Markovic N, Bass D, Harger G, Roberts JM. Family history of hypertension, heart disease, and stroke among women who develop hypertension in pregnancy. Obstet Gynecol. 2003;102(6):1366-71.

16. Abetew DF, Enquobahrie DA, Dishi M, Rudra CB, Miller RS, Williams MA. Age at Menarche, Menstrual Characteristics, and Risk of Preeclampsia. ISRN Obstet Gynecol. 2011;2011:472083. doi:10.5402/2011/472083

17. Rudra CL, Williams MA. BMI as a modifying factor in the relations between age at menarche, menstrual cycle characteristics, and risk of preeclampsia. Gynecol Endocrinol. 2005;21(4):200-205. 
18. Day FR, Elks CE, Murray A, Ong KK, Perry JRB. Puberty timing associated with diabetes, cardiovascular disease and also diverse health outcomes in men and women: the UK Biobank study. Sci Rep 2015;5:11208. doi:10.1038/srep11208

19. Rolnik DL, Wright D, Poon LC, O’Gorman N, Syngelaki A, de Paco Matallana C, et al. Aspirin versus Placebo in Pregnancies at High Risk for Preterm Preeclampsia. N Engl J Med 2017;377(7):613-622. doi: 10.1056/NEJMoa1704559

20. Jääskeläinen T, Heinonen S, Kajantie E, Kere J, Kivinen K, Pouta A, et al. Cohort profile: The Finnish Genetics of Pre-eclampsia Consortium (FINNPEC). BMJ Open 2016;6:e013148. doi:10.1136/bmjopen2016-013148

21. ACOG Committee on Practice Bulletins-Obstetrics. ACOG practice bulletin. Diagnosis and management of preeclampsia and eclampsia. Number 33, January 2002. Obstet Gynecol. 2002;99:159-67.

22. Palmer KT, Bonzini M, Harris EC, Linaker C, Bonde JP. Work activities and risk of prematurity, low birth weight and pre-eclampsia: An updated review with meta-analysis. Occup Environ Med. 2013;70(4):21322. doi:10.1136/oemed-2012-101032

23. Jansen PW, Tiemeier H, Verhulst FC, Burdorf A, Jaddoe VWV, Hofman A, et al. Employment status and the risk of pregnancy complications: The Generation R Study. Occup Environ Med. 2010;67(6):387-94.

24. Spracklen CN, Smith CJ, Saftlas AF, Robinson JG, Ryckman KK. Maternal hyperlipidemia and the risk of preeclampsia: A meta-analysis. Am J Epidemiol. 2014;180(4):346-58.

25. Berk M, Williams LJ, Jacka FN, O’Neil A, Pasco JA, Moylan S, et al. So depression is an inflammatory disease, but where does the inflammation come from? BMC Med. 2013;11:200. doi:10.1186/17417015-11-200

26. Lupattelli A, Wood M, Lapane K, Spigset O, Nordeng H. Risk of preeclampsia after gestational exposure to selective serotonin reuptake inhibitors and other antidepressants: A study from The Norwegian Mother and Child Cohort Study. Pharmacoepidemiol Drug Saf. 2017;26(10):1266-76.

27. De Ocampo MPG, Araneta MRG, Macera CA, Alcaraz JE, Moore TR, Chambers CD. Risk of gestational hypertension and preeclampsia in women who discontinued or continued antidepressant medication use during pregnancy. Arch Womens Ment Health. 2016;19(6):1051-61.

28. Roes EM, Sieben R, Raijmakers MTM, Peters WHM, Steegers EAP. Severe preeclampsia is associated with a positive family history of hypertension and hypercholesterolemia. Hypertens Pregnancy. 2005;24(3):259-71.

29. Rigó J, Boze T, Derzsy Z, Derzbach L, Treszl A, Lázár L, et al. Family history of early-onset cardiovascular disorders is associated with a higher risk of severe preeclampsia. Eur J Obstet Gynecol Reprod Biol. 2006;128(1-2):148-51.

30. Qiu C, Williams MA, Leisenring WM, Sorensen TK, Frederick IO, Dempsey JC, et al. Family History of Hypertension and Type 2 Diabetes in Relation to Preeclampsia Risk. Hypertension. 2003;41(3):408-13.

31. Sun X, Yang L, Pan J, Yang H, Wu Y, Chen Z, et al. Age at menarche and the risk of gestational diabetes mellitus: a systematic review and meta-analysis. Endocrine. 2018;61(2):204-209.

32. Lakshman R, Forouhi NG, Sharp SJ, Luben R, Bingham SA, Khaw KT, et al. Early age at menarche associated with cardiovascular disease and mortality. J Clin Endocrinol Metab. 2009;94(12):4953-4960. 
33. Weissgerber TL, Mudd LM. Preeclampsia and diabetes. Curr Diab Rep. 2015;15(3):9. doi:10.1007/s11892-015-0579-4

34. Wu P, Haththotuwa R, Kwok CS, Babu A, Kotronias RA, Rushton C, et al. Preeclampsia and Future Cardiovascular Health: A Systematic Review and Meta-Analysis. Circ Cardiovasc Qual Outcomes. 2017;10:e003497. DOI: 10.1161/CIRCOUTCOMES.116.003497

35. Petry CJ, Ong KK, Hughes IA, Acerini CL, Dunger DB. Age at menarche and blood pressure in pregnancy. Pregnancy Hypertens. 2019;15:134-40.

36. Clancy KBH, Klein LD, Ziomkiewicz A, Nenko I, Jasienska G, Bribiescas RG. Relationships between biomarkers of inflammation, ovarian steroids, and age at menarche in a rural polish sample. Am J Hum Biol. 2013;25(3):389-398.

37. Berg AH, Scherer PE. Adipose Tissue, Inflammation, and Cardiovascular Disease. Circ Res. 2005;96(9):939-949.

38. Thomson F, Shanbhag S, Templeton A, Bhattachrya S. Obstetric outcome in women with subfertility. BJOG. 2005;112(5):632-637.

39. DoPierala AL, Bhatta S, Raja EA, Bhattacharya S, Bhattacharya S. Obstetric consequences of subfertility: a retrospective cohort study. BJOG. 2016;123(8):1320-1328.

40. Jaques AM, Amor DJ, Baker HWG, Healy DL, Ukoumunne OC, Breheny S, et al. Adverse obstetric and perinatal outcomes in subfertile women conceiving without assisted reproductive technologies. Fertil Steril. 2010;94(7):2674-2679.

41. Basso O, Weinberg CR, Baird DD, Wilcox AJ, Olsen J. Subfecundity as a correlate of preeclampsia: A study within the Danish National Birth Cohort. Am J Epidemiol. 2003;157(3):195-202.

42. Wise LA, Mikkelsen EM, Sørensen HT, Rothman KJ, Hahn KA, Riis AH, et al. Prospective study of time to pregnancy and adverse birth outcomes. Fertil Steril. 2015;103(4):1065-1073.e2.

doi:10.1016/j.fertnstert.2015.01.024

43. Palomba S, Homburg R, Santagni S, La Sala GB, Orvieto R. Risk of adverse pregnancy and perinatal outcomes after high technology infertility treatment: a comprehensive systematic review. Reprod Biol Endocrinol. 2016;14(1):76.

44. Thomopoulos C, Tsioufis C, Michalopoulou H, Makris T, Papademetriou V, Stefanadis C. Assisted reproductive technology and pregnancy-related hypertensive complications: A systematic review. J Hum Hypertens. 2013;27(3):148-57.

45. Omani-Samani R, Alizadeh A, Almasi-Hashiani A, Mohammadi M, Maroufizadeh S, Navid B, et al. Risk of preeclampsia following assisted reproductive technology: systematic review and meta-analysis of 72 cohort studies. J Matern Neonatal Med. DOI: 10.1080/14767058.2018.1560406

46. Hayashi M, Nakai A, Satoh S, Matsuda Y. Adverse obstetric and perinatal outcomes of singleton pregnancies may be related to maternal factors associated with infertility rather than the type of assisted reproductive technology procedure used. Fertil Steril. 2012;98(4):922-8.

47. Vannuccini S, Clifton VL, Fraser IS, Taylor HS, Critchley H, Giudice LC, et al. Infertility and reproductive disorders: impact of hormonal and inflammatory mechanisms on pregnancy outcome. Hum Reprod Update. 2016;22(1):104-115. 
48. Johnson TP, Wislar JS. Response rates and nonresponse errors in surveys. JAMA. 2012;307(17):18051806.

\section{Declarations}

\section{Ethics approval and consent to participate}

The FINNPEC study protocol was approved by the coordinating Ethics Committee of the Hospital District of Helsinki and Uusimaa. All participants signed a written informed consent.

\section{Consent for publication}

Not applicable.

\section{Competing interests}

The authors declare that they have no competing interests.

\section{Availability of data and materials}

The authors confirm that some access restrictions apply to the data. The researchers interested in using the data must obtain approval from the FINNPEC Board (steering committee). The researchers using the data are required to follow the terms of a number of clauses designed to ensure the protection of privacy and compliance with relevant Finnish laws. Data requests may be subject to further review by the Ethics Committee and may also be subject to individual participant consent.

\section{Funding}

The FINNPEC study was supported by Jane and Aatos Erkko Foundation, Juho Vainio Foundation, Päivikki and Sakari Sohlberg Foundation, Academy of Finland, Research Funds of the University of Helsinki, Government special state subsidy for health sciences at the Hospital District of

Helsinki and Uusimaa, Finska Läkaresällskapet, Liv och Hälsa Foundation, Novo Nordisk Foundation, Finnish Foundation for Pediatric Research, Emil Aaltonen Foundation, Sigrid Juselius

Foundation, and Finnish Foundation for Laboratory Medicine. NJ was supported by The State Research Financing of the local hospital (Seinäjoki Central Hospital) and The Research fund of obstetrics and gynecology in southwestern Finland.

\section{Authors' contributions}


$\mathrm{NJ}, \mathrm{TJ}, \mathrm{HL}$ and EE designed the research. $\mathrm{NJ}$ analyzed the data and wrote the first draft of the manuscript. TJ, $\mathrm{HL}$ and EE contributed to the data analysis and interpretation and revised the manuscript. All authors read and approved the final manuscript.

\section{Acknowledgements}

We appreciate the expert technical assistance of Eija Kortelainen and Susanna Mehtälä and contribution of the members and assisting personnel of the FINNPEC Study Group. We would also like to acknowledge MSc Saija Hurme for helping with analyzing the data.

\section{The Finnish Genetics of Pre-Eclampsia Consortium (FINNPEC) core investigator group}

Hannele Laivuori, principal investigator

Medical and Clinical Genetics, University of Helsinki and Helsinki University Hospital

Institute for Molecular Medicine Finland, Helsinki Institute of Life Science, University of Helsinki

Department of Obstetrics and Gynecology, Tampere University Hospital and Tampere University, Faculty of Medicine and Health Technology.

Seppo Heinonen

Obstetrics and Gynecology, University of Helsinki and Helsinki University Hospital

Eero Kajantie

PEDEGO Research Unit, Medical Research Center Oulu, Oulu University Hospital and University of Oulu

Public Health Promotion Unit, National Institute for Health and Welfare, Helsinki and Oulu

Children's hospital, University of Helsinki and Helsinki University Hospital

Department of Clinical and Molecular Medicine, Norwegian University of Health and Technology, Trondheim, Norway

Juha Kere

Department of Biosciences and Nutrition, Karolinska Institutet, Huddinge, Sweden.

Folkhälsan Institute of Genetics and Molecular Neurology Research Program, University of Helsinki,

School of Basic \& Medical Biosciences, King's College London, London, England 
Katja Kivinen

Division of Cardiovascular Medicine, University of Cambridge, United Kingdom

Anneli Pouta

Department of Government Services, National Institute for Health and Welfare, Helsinki

\section{Tables}

Table 1. Basic maternal characteristics

\begin{tabular}{|c|c|c|c|c|c|c|c|c|}
\hline & \multicolumn{2}{|c|}{$\begin{array}{c}\text { Preeclampsia } \\
(n=708)\end{array}$} & \multicolumn{3}{|c|}{ Healthy controls $(n=498)$} & \multicolumn{3}{|c|}{ All controls $(n=724)$} \\
\hline & $\mathbf{N}$ & $\begin{array}{r}\% \text { or } \\
\text { median } \\
\text { (range) }\end{array}$ & $\mathbf{N}$ & $\begin{array}{r}\text { \% or } \\
\text { median } \\
\text { (range) }\end{array}$ & $p$ value & $\mathbf{N}$ & $\begin{array}{r}\% \text { or } \\
\text { median } \\
\text { (range) }\end{array}$ & $p$ value \\
\hline $\begin{array}{l}\text { Age at } \\
\text { delivery }\end{array}$ & $(n=707)$ & $\begin{array}{r}29.9 \\
(5.6)^{\mathrm{a}}\end{array}$ & & $\begin{array}{r}29.7 \\
(5.2)^{\mathrm{a}} \\
\end{array}$ & 0.596 & $(n=721)$ & $\begin{array}{r}29.9 \\
(5.1)^{\mathrm{a}}\end{array}$ & 0.887 \\
\hline Nulliparous & $\begin{array}{r}535 \\
(n=707) \\
\end{array}$ & 75.7 & 263 & 52.8 & $<0.001$ & $\begin{array}{r}404 \\
(n=721)\end{array}$ & 56.0 & $<0.001$ \\
\hline $\begin{array}{l}\text { BMI, } \mathrm{kg} / \mathrm{m}^{2} \\
\text { (self-reported, } \\
\text { pre- } \\
\text { pregnancy) }\end{array}$ & $(\mathrm{n}=707)$ & $\begin{array}{r}24.0 \\
(16.2- \\
47.3)\end{array}$ & & $\begin{array}{r}22.7 \\
(17.0- \\
38.4)\end{array}$ & $<0.001$ & $(n=721)$ & $\begin{array}{r}23.1 \\
(17.0- \\
47.4)\end{array}$ & $<0.001$ \\
\hline $\begin{array}{l}\text { Smoking } \\
\text { before } \\
\text { preqnancy }\end{array}$ & $\begin{array}{r}208 \\
(\mathrm{n}=696)\end{array}$ & 29.9 & $\begin{array}{r}137 \\
(\mathrm{n}=487)\end{array}$ & 28.1 & 0.514 & $\begin{array}{r}209 \\
(\mathrm{n}=708)\end{array}$ & 29.5 & 0.881 \\
\hline $\begin{array}{l}\text { Smoking } \\
\text { during } \\
\text { pregnancy }\end{array}$ & $\begin{array}{r}63 \\
(\mathrm{n}=700)\end{array}$ & 9.0 & $\begin{array}{r}58 \\
(\mathrm{n}=497)\end{array}$ & 11.7 & 0.131 & $\begin{array}{r}85 \\
(n=720)\end{array}$ & 11.8 & 0.084 \\
\hline $\begin{array}{l}\text { Mode of } \\
\text { delivery }\end{array}$ & $(n=707)$ & & & & $<0.001$ & $(n=723)$ & & $<0.001$ \\
\hline Vaginal & 426 & 60.3 & 440 & 88.4 & & 614 & 84.9 & \\
\hline section & 281 & 39.7 & 58 & 11.6 & & 109 & 15.1 & \\
\hline $\begin{array}{l}\text { Gestational } \\
\text { weeks at } \\
\text { delivery } \\
\end{array}$ & $(\mathrm{n}=707)$ & $\begin{array}{r}38(24- \\
42)\end{array}$ & & $\begin{array}{r}40(36- \\
43) \\
\end{array}$ & $<0.001$ & $(n=723)$ & $\begin{array}{r}40(23- \\
43) \\
\end{array}$ & $<0.001$ \\
\hline
\end{tabular}

${ }^{\mathrm{a}}$ mean (SD)

Bold text shows p values $<0.05$

( ) Number of available information unless from all

Table 2. Socioeconomic factors 


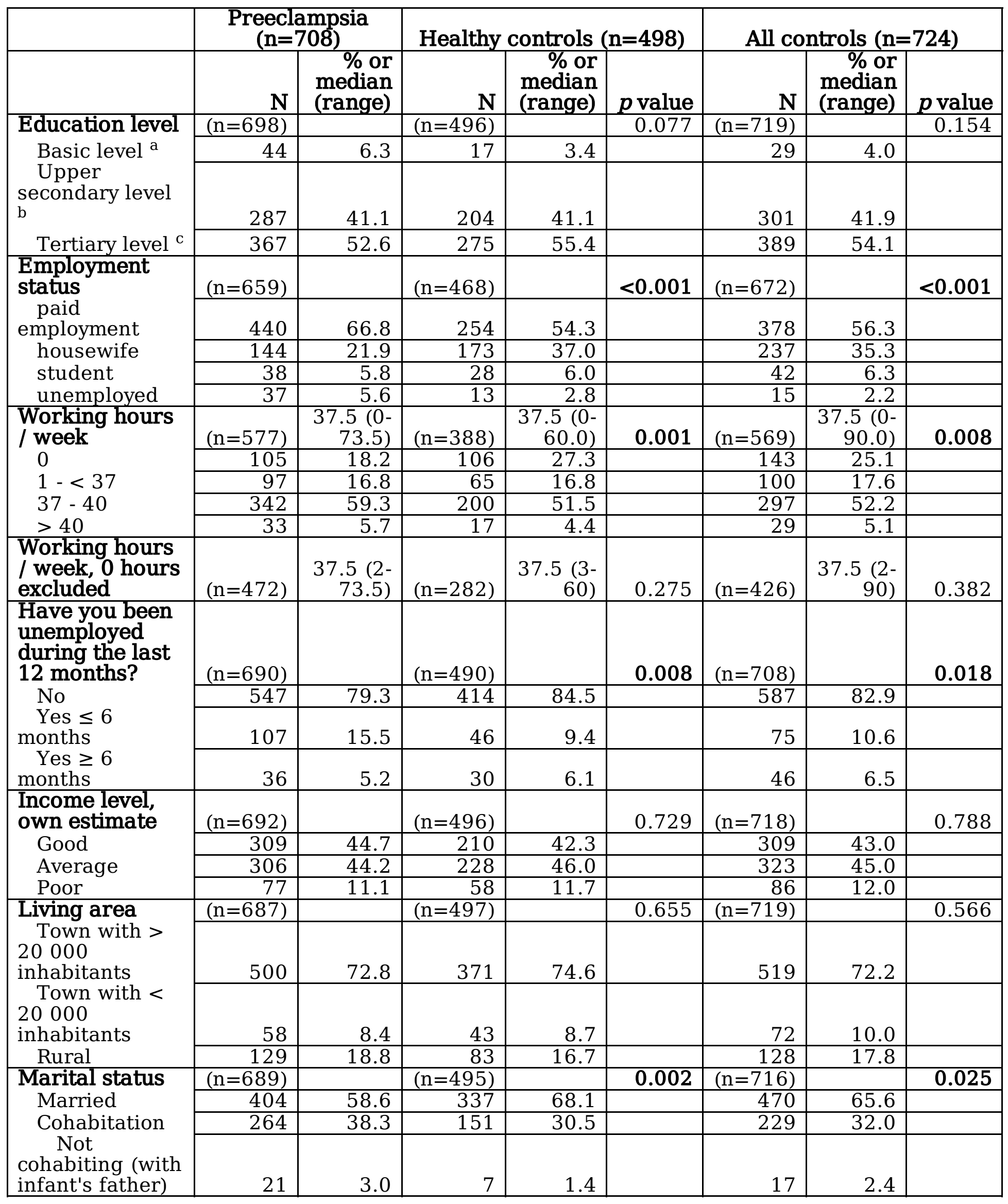


b 11 to 12 years of education

c 3-6 years of education after upper secondary level, includes polytechnic degrees and lower university degrees, higher university degrees (master's degree) and specialist's degrees in medicine

Bold text shows $\mathrm{p}$ values $<0.05$

( ) Number of available information unless from all

Table 3. Health and pregnancy information 


\begin{tabular}{|c|c|c|c|c|c|c|c|c|}
\hline & \multicolumn{2}{|c|}{$\begin{array}{c}\text { Preeclampsia } \\
(\mathrm{n}=708)\end{array}$} & \multicolumn{3}{|c|}{ Healthy controls $(n=498)$} & \multicolumn{3}{|c|}{ All controls $(n=724)$} \\
\hline & $\mathbf{N}$ & $\begin{array}{l}\% \text { or } \\
\text { median } \\
\text { (range) }\end{array}$ & $\mathbf{N}$ & $\begin{array}{r}\begin{array}{r}\% \text { or } \\
\text { median } \\
\text { (range) }\end{array} \\
\end{array}$ & $\begin{array}{r}\mathbf{p} \\
\text { value }\end{array}$ & $\mathbf{N}$ & $\begin{array}{r}\% \text { or } \\
\text { median } \\
\text { (range) }\end{array}$ & $p$ value \\
\hline \multicolumn{9}{|l|}{$\begin{array}{l}\text { HEALTH } \\
\text { INFORMATION }\end{array}$} \\
\hline \multirow{4}{*}{$\begin{array}{l}\text { Health status, } \\
\text { own estimation } \\
\text { Good } \\
\text { Average } \\
\text { Poor }\end{array}$} & $(\mathrm{n}=694)$ & & $(\mathrm{n}=493)$ & & $<0.001$ & $(n=716)$ & & $<0.001$ \\
\hline & 541 & 78.0 & 455 & 92.3 & & 636 & 88.8 & \\
\hline & 133 & 19.2 & 34 & 6.9 & & 67 & 9.4 & \\
\hline & 20 & 2.9 & 4 & 0.8 & & 13 & 1.8 & \\
\hline \multirow{4}{*}{$\begin{array}{l}\text { Number of sick } \\
\text { days during last } \\
12 \text { months } \\
\text { a } \\
<5 \\
5-10 \\
>10\end{array}$} & $(\mathrm{n}=436)$ & $\begin{aligned} 5(0- \\
75)\end{aligned}$ & $(\mathrm{n}=248)$ & $\begin{array}{r}5(0- \\
60)\end{array}$ & 0.823 & $(\mathrm{n}=370)$ & $\begin{array}{l}5(0- \\
120)\end{array}$ & 0.936 \\
\hline & 210 & 48.2 & 124 & 50.0 & & 185 & 50.0 & \\
\hline & 152 & 34.9 & 93 & 37.5 & & 134 & 36.2 & \\
\hline & 74 & 17.0 & 31 & 12.5 & & 51 & 13.8 & \\
\hline \multirow{4}{*}{$\begin{array}{l}\text { Age at } \\
\text { menarche } \\
\text { (years) } \\
11-15 \\
<11 \\
>15\end{array}$} & $(\mathrm{n}=688)$ & $\begin{array}{r}13.0 \\
(9.0- \\
17.0) \\
\end{array}$ & $(\mathrm{n}=490)$ & $\begin{array}{r}13.0 \\
(10.0- \\
18.0) \\
\end{array}$ & 0.001 & $(\mathrm{n}=708)$ & $\begin{array}{l}13.0 \\
(9.0- \\
18.0) \\
\end{array}$ & 0.022 \\
\hline & 650 & 94.5 & 464 & 94.7 & & 669 & 94.5 & \\
\hline & 29 & 4.2 & 8 & 1.6 & & 14 & 2.0 & \\
\hline & 9 & 1.3 & 18 & 3.7 & & 25 & 3.5 & \\
\hline \multicolumn{9}{|l|}{$\begin{array}{l}\text { PREGNANCY } \\
\text { INFORMATION }\end{array}$} \\
\hline \multirow{4}{*}{$\begin{array}{l}\text { Time to } \\
\text { pregnancy } \\
\text { (months) } \\
\leq 3 \\
>3-12 \\
>12\end{array}$} & $(\mathrm{n}=639)$ & $\begin{array}{l}3(0- \\
144)\end{array}$ & $(\mathrm{n}=461)$ & $\begin{array}{l}2(0- \\
144)\end{array}$ & 0.013 & $(\mathrm{n}=670)$ & $\begin{array}{l}2(0- \\
144)\end{array}$ & 0.019 \\
\hline & 361 & 56.5 & $\begin{array}{r}296 \\
\end{array}$ & 64.2 & & 427 & 63.7 & \\
\hline & 171 & 26.8 & 108 & 23.4 & & 157 & 23.4 & \\
\hline & 107 & 16.7 & 57 & 12.4 & & 86 & 12.8 & \\
\hline $\begin{array}{l}\text { Morning } \\
\text { sickness }\end{array}$ & $\begin{array}{r}610 \\
(\mathrm{n}=696)\end{array}$ & 87.6 & $\begin{array}{r}454 \\
(\mathrm{n}=496)\end{array}$ & 91.5 & 0.033 & $\begin{array}{r}649 \\
(\mathrm{n}=717)\end{array}$ & 90.5 & 0.083 \\
\hline $\begin{array}{l}\text { Morning } \\
\text { sickness, degree } \\
\text { of difficulty, } \\
\text { scale } 0-100\end{array}$ & $(\mathrm{n}=696)$ & $\begin{array}{r}20(0- \\
100) \\
\end{array}$ & $(\mathrm{n}=496)$ & $\begin{array}{r}18(0- \\
100) \\
\end{array}$ & 0.990 & $(\mathrm{n}=717)$ & $\begin{array}{r}18(0- \\
100) \\
\end{array}$ & 0.964 \\
\hline \multirow{2}{*}{$\begin{array}{l}\text { Assisted } \\
\text { reproductive } \\
\text { technology } \\
\text { (ART) } \\
\text { Any treatment } \\
\text { Clomiphene }\end{array}$} & $(\mathrm{n}=671)$ & & $(\mathrm{n}=469)$ & & 0.157 & $(\mathrm{n}=680)$ & & 0.143 \\
\hline & 84 & 12.5 & 46 & 9.8 & & 68 & 10.0 & \\
\hline \multirow{2}{*}{$\begin{array}{l}\text { stimulation } \\
\text { Insemination } \\
\text { Surgical }\end{array}$} & 27 & 4.0 & 20 & 4.3 & 0.841 & 25 & 3.7 & 0.740 \\
\hline & 30 & 4.5 & 13 & 2.8 & 0.138 & 18 & 2.6 & 0.070 \\
\hline \multirow{2}{*}{$\begin{array}{l}\text { treatment } \\
\text { In vitro } \\
\text { fertilization } \\
\text { (IVF) }\end{array}$} & 5 & 0.7 & 0 & 0 & 0.061 & 1 & 0.1 & 0.098 \\
\hline & 40 & 6.0 & 17 & 3.6 & 0.075 & 27 & 4.0 & 0.092 \\
\hline \multirow{2}{*}{$\begin{array}{l}\text { Intracytoplasmic } \\
\text { sperm injection } \\
\text { (ICSI) } \\
\text { Other } \\
\text { treatment }\end{array}$} & 10 & 1.5 & 6 & 1.3 & 0.766 & 7 & 1.0 & 0.447 \\
\hline & 17 & 2.5 & 10 & 2.1 & 0.661 & 15 & 2.2 & 0.692 \\
\hline
\end{tabular}


a among employed women, does not include absences related to pregnancy Bold text shows $\mathrm{p}$ values $<0.05$

( ) Number of available information unless from all

Table 4. Pre-existing medical conditions

\begin{tabular}{|c|c|c|c|c|c|c|c|c|}
\hline & \multicolumn{2}{|c|}{$\begin{array}{l}\text { Preeclampsia } \\
(\mathrm{n}=708)\end{array}$} & \multicolumn{3}{|c|}{$\begin{array}{c}\text { Healthy controls } \\
(\mathrm{n}=498)\end{array}$} & \multicolumn{3}{|c|}{ All controls $(n=724)$} \\
\hline & $\mathbf{N}$ & $\%$ & $\mathrm{~N}$ & $\%$ & $p$ value & $\mathbf{N}$ & $\%$ & $p$ value \\
\hline $\begin{array}{l}\text { Any pre-existing } \\
\text { medical condition }\end{array}$ & $\begin{array}{r}93 \\
(\mathrm{n}=694)\end{array}$ & 13.4 & $\begin{array}{r}29 \\
(n=497)\end{array}$ & 5.8 & $<0.001$ & $\begin{array}{r}66 \\
(\mathrm{n}=718)\end{array}$ & 9.2 & 0.012 \\
\hline Type I diabetes & $\begin{array}{r}19 \\
(\mathrm{n}=666)\end{array}$ & 2.9 & $\begin{array}{r}0 \\
(n=483)\end{array}$ & 0 & $<0.001$ & $\begin{array}{r}4 \\
(\mathrm{n}=691)\end{array}$ & 0.6 & 0.001 \\
\hline Type II diabetes & $5(\mathrm{n}=664)$ & 0.8 & $\begin{array}{r}0 \\
(n=483)\end{array}$ & 0 & 0.056 & $\begin{array}{r}5 \\
(n=692)\end{array}$ & 0.7 & 0.948 \\
\hline Chronic hypertension & $\begin{array}{r}55 \\
(\mathrm{n}=665) \\
\end{array}$ & 8.3 & $\begin{array}{r}0 \\
(\mathrm{n}=483) \\
\end{array}$ & 0 & $<0.001$ & $\begin{array}{r}18 \\
(\mathrm{n}=692) \\
\end{array}$ & 2.6 & $<0.001$ \\
\hline Hypercholesterolemia & $\begin{array}{r}37 \\
(\mathrm{n}=664)\end{array}$ & 5.6 & $\begin{array}{r}10 \\
(n=483)\end{array}$ & 2.1 & 0.003 & $\begin{array}{r}14 \\
(n=691)\end{array}$ & 2.0 & 0.001 \\
\hline Allergic rhinitis & $\begin{array}{r}159 \\
(\mathrm{n}=669)\end{array}$ & 23.8 & $\begin{array}{r}127 \\
(\mathrm{n}=487)\end{array}$ & 26.1 & 0.369 & $\begin{array}{r}179 \\
(\mathrm{n}=697)\end{array}$ & 25.7 & 0.412 \\
\hline Asthme & $\begin{array}{r}74 \\
(\mathrm{n}=664) \\
\end{array}$ & 11.1 & $\begin{array}{r}37 \\
(\mathrm{n}=480) \\
\end{array}$ & 7.7 & 0.053 & $\begin{array}{r}67 \\
(\mathrm{n}=687) \\
\end{array}$ & 9.8 & 0.403 \\
\hline Atopic dermatitis & $\begin{array}{r}106 \\
(\mathrm{n}=662) \\
\end{array}$ & 16.0 & $\begin{array}{r}83 \\
(\mathrm{n}=484) \\
\end{array}$ & 17.1 & 0.609 & $\begin{array}{r}118 \\
(\mathrm{n}=688) \\
\end{array}$ & 17.2 & 0.574 \\
\hline Other allergic disease & $\begin{array}{r}81 \\
(\mathrm{n}=649) \\
\end{array}$ & 12.5 & $\begin{array}{r}56 \\
(\mathrm{n}=482) \\
\end{array}$ & 11.6 & 0.660 & $\begin{array}{r}93 \\
(\mathrm{n}=688) \\
\end{array}$ & 13.5 & 0.573 \\
\hline Depression & $\begin{array}{r}76 \\
(n=668) \\
\end{array}$ & 11.4 & $\begin{array}{r}32 \\
(n=483) \\
\end{array}$ & 6.6 & 0.006 & $\begin{array}{r}53 \\
(n=693) \\
\end{array}$ & 7.6 & 0.019 \\
\hline Panic disorder & $\begin{array}{r}24 \\
(\mathrm{n}=662) \\
\end{array}$ & 3.6 & $\begin{array}{r}17 \\
(\mathrm{n}=483) \\
\end{array}$ & 3.5 & 0.924 & $\begin{array}{r}23 \\
(\mathrm{n}=692) \\
\end{array}$ & 3.3 & 0.762 \\
\hline Other mental disorder & $\begin{array}{r}16 \\
(\mathrm{n}=662) \\
\end{array}$ & 2.4 & $\begin{array}{r}6 \\
(\mathrm{n}=482) \\
\end{array}$ & 1.2 & 0.154 & $\begin{array}{r}11 \\
(\mathrm{n}=690) \\
\end{array}$ & 1.6 & 0.280 \\
\hline
\end{tabular}

Bold text shows $\mathrm{p}$ values $<0.05$

( ) Number of available information unless from all

Table 5. Regular/seasonal medication during last 12 months 


\begin{tabular}{|c|c|c|c|c|c|c|c|c|}
\hline & \multicolumn{2}{|c|}{$\begin{array}{c}\text { Pre-eclampsia } \\
(\mathrm{n}=708)\end{array}$} & \multicolumn{3}{|c|}{$\begin{array}{l}\text { Healthy controls } \\
(\mathrm{n}=498)\end{array}$} & \multicolumn{3}{|c|}{$\begin{array}{c}\text { All controls } \\
(n=724)\end{array}$} \\
\hline & $\mathbf{N}$ & $\%$ & $\mathbf{N}$ & $\%$ & $p$ value & $\mathbf{N}$ & $\%$ & $p$ value \\
\hline Any medication & 222 & 31.4 & 105 & 21.1 & $<0.001$ & 201 & 27.8 & 0.136 \\
\hline Psychiatric medication & 27 & 3.8 & 11 & 2.2 & 0.116 & 23 & 3.2 & 0.512 \\
\hline $\begin{array}{l}\text { Selective serotonin reuptake } \\
\text { inhibitors (SSRI) }\end{array}$ & 26 & 37 & 6 & 12 & 0.009 & 16 & & 0101 \\
\hline Asthma medication & 34 & 4.8 & $\frac{0}{15}$ & 3.0 & 0.121 & $\frac{10}{32}$ & $\frac{2.2}{4.4}$ & $\frac{0.101}{0.730}$ \\
\hline Levothyroxine & 25 & 3.5 & 9 & 1.8 & 0.076 & 22 & 3.0 & 0.601 \\
\hline Antihistamine & 41 & 5.8 & 28 & 5.6 & 0.901 & 45 & 6.2 & 0.735 \\
\hline Intranasal steroids & 20 & 2.8 & 15 & 3.0 & 0.849 & 22 & 3.0 & 0.811 \\
\hline IBD a or rheumatic disease & & & & & & & & \\
\hline $\begin{array}{l}\text { medication } \\
\text { Aspirin }\end{array}$ & $\frac{10}{6}$ & $\frac{1.4}{0.8}$ & $\frac{4}{2}$ & $\frac{0.8}{0.4}$ & $\frac{0.331}{0.348}$ & $\frac{8}{3}$ & $\frac{1.1}{0.4}$ & $\frac{0.602}{0.300}$ \\
\hline Low-molecular-weight heparin & 5 & 0.7 & 7 & 1.4 & 0.228 & 9 & 1.2 & 0.302 \\
\hline Insulin & 23 & 3,2 & 0 & 0 & $<0.001$ & 6 & 0.8 & 0.001 \\
\hline Metformin & 6 & 0.8 & 0 & 0 & 0.040 & 2 & 0.3 & 0.147 \\
\hline Proton pump inhibitors & 6 & 0.8 & 2 & 0.4 & 0.348 & 4 & 0.6 & 0.503 \\
\hline Anti hypertensive agents & 56 & 7.9 & 4 & 0.8 & $<0.001$ & 26 & 3.6 & $<0.001$ \\
\hline Labetalol & 45 & 6.4 & 0 & 0 & $<0.001$ & 16 & 2.2 & $<0.001$ \\
\hline Nifedipine & 13 & 1.8 & 0 & $\underline{0}$ & 0.002 & 2 & 0.3 & 0.004 \\
\hline ACE inhibitor ${ }^{b} / A^{2} B^{c}$ & 12 & 1.7 & 0 & 0 & 0.004 & 4 & 0.6 & 0.040 \\
\hline Other beta blocker & 4 & 0.6 & 4 & 0.8 & 0.616 & 8 & 1.1 & 0.262 \\
\hline Other medication & 41 & 5.8 & 30 & 6 & 0.866 & 50 & 6.9 & 0.387 \\
\hline
\end{tabular}

\author{
a Inflammatory bowel disease \\ b Angiotensin-converting enzyme inhibitor \\ ${ }^{\mathrm{c}}$ Angiotensin II receptor blocker \\ Bold text shows $\mathrm{p}$ values $<0.05$
}

Table 6. Information on study participants' parents. 


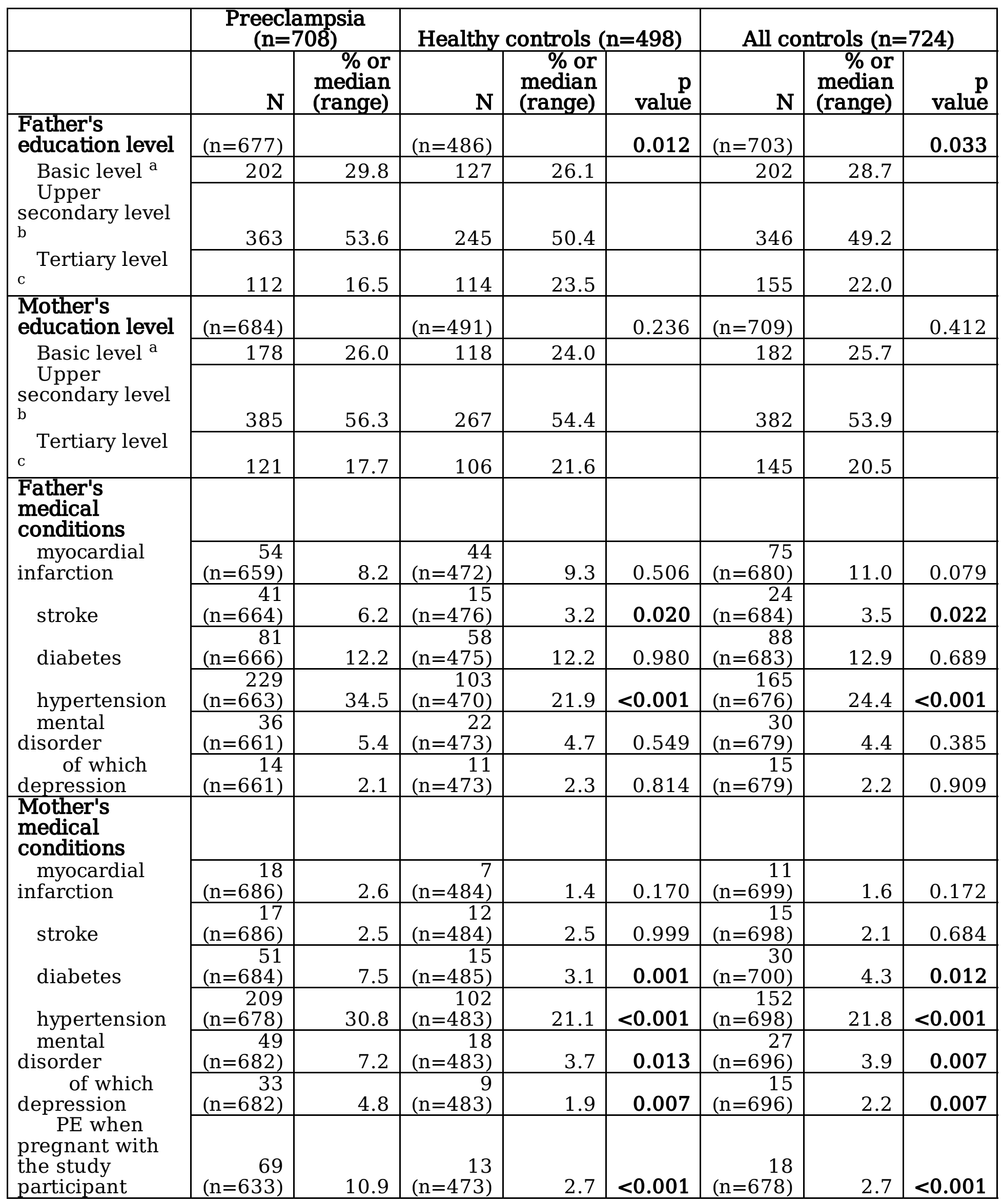

${ }^{a}$ at most nine years of education 
b 11 to 12 years of education

c 3-6 years of education after upper secondary level, includes polytechnic degrees and lower university degrees, higher university degrees (master's degree) and specialist's degrees in medicine

Bold text shows $\mathrm{p}$ values $<0.05$

( ) Number of available information unless from all 